Ophthalmologica 1982;185:I-IV

\title{
Contents, Vol. 185, 1982
}

No. 1 Original Paper $\cdot$ Travaux originaux $\cdot$ Originalarbeiten

Angeborene isolierte Fibromatose des Lides

Witschel, $\mathrm{H} \quad 1$

Diffuse Retinal Pigment Epitheliopathy

Winning, C.H.O.M. von; Oosterhuis, J.A.; Renger-van Dijk, A.H.; Hornstra-Limburg, H.; Polak, B.C.P 7

Functional Importance of Central Retinal Artery Anastomoses in the Anterior Part of the Optic Nerve

Francois, J.; Fryczkowski, A 15

Peripheral Response of the Retina to Polarized Light

Gerharz, R 26

Augenveränderungen bei Oxalose

Richard, G.; Promesberger, H 32

Leukemic Optic Neuropathy

Takahashi, T.; Oda, Y.; Isayama, Y 37

Rat Cornea in Experimental Protein Deficiency

Ratnakar, K.S.; Gowreswaramma, P 46

Clinicopathologic Case Report

Bindehautmetastase eines primären Hautmelanoms

Strempel, $1 \quad 52$

Book Reviews · Livres nouveaux · Buchbesprechungen 58

Announcement $\cdot$ Communication $\cdot$ Ankündigung 60

No. 2 Original Paper - Travaux originaux - Originalarbeiten

Families with Retinitis Pigmentosa: Problems in the Analysis of Sporadic, Simplex and Multiplex Cases

Jay, M.; Jay, B

Metastatic Serratia marcescens Endophthalmitis

Radda, T.M 65

Augenmanifestationen der Wegenerschen Granulomatose

Kuchynka, P 69

Eye and Orbital Size in the Young and Adult. Some Postnatal Experimental and Clinical

Relationships

Sarnat, B.G 74

Eine einfache Methode zur Uberprüfung der Sehschärfe des Einzelauges in der Feme bei Nystagmus

Haase, W.; Schulz, C.P 90

Proceedings - Comptes rendus - Verhandlungsberichte

Netherlands Ophthalmological Society. 175th Annual Meeting, March 25-27, 1981, Amhem 94

Book Reviews · Livres nouveaux · Buchbesprechungen 119 
IV Index

No. 3 Diseases of the Retina and Uvea

Retinal Involvement in Familial Exudative Vitreoretinopathy

Miyakubo, H.; Inohara, N.; Hashimoto, K 125

Genetics of Lattice Degeneration of the Retina

Murakami, F.; Ohba, N 136

Perifoveal Capillary Network and Visual Prognosis in Diabetic Retinopathy

Tamura, T.; Tamura, M 141

Retinal Vascular Patterns in the Macula and the Perimacular Area in Premature and Full-Term Infants

Nishimura, M.; Taniguchi, Y 147

Radiation Effects on Retinoblastoma Successively Transplanted into Nude Mouse Eyes

Totsuka, S.; Minoda, K 158

Experimental Central Serous Chorioretinopathy in Monkey Eyes: Fluorescein Angiographic

Findings

Yoshioka, H.; Katsume, Y.; Akune, H 168

The Role of Cytotoxic T Lymphocytes in the Pathogenesis of Vogt-Koyanagi-Harada

Disease

Maezawa, N.; Yano, A.; Taniguchi, M.; Kojima, S 179

Studies of Spontaneous Production of Gamma-Interferon in Behçet's Disease

Ohno, S.; Kato, F.; Matsuda, H.; Fujii, N.; Minagawa, T 187

No. 4 Original Paper · Travaux originaux $\cdot$ Originalarbeiten

Microsurgery of Persistent Hyperplastic Primary Vitreous

Laatikainen, L.; Tarkkanen, A 193

Aetiopathogenesis of Degenerative Myopia. A Hypothesis

Balacco-Gabrieli, C 199

Virus-Induced Pigment Epithelitis in Rhesus Monkeys. Clinical and Histological Findings

Krey, H.F.; Stitz, L.; Ludwig, H 205

Eye Involvement in Waldenström's Macroglobulinaemia

Giarelli, L.; Melato, M.; Falconieri, G 214

Fixation Disparity in Vertical Vergence

Houtman, W.A.; Pol, B.A.E. van der 220

Superficial Annular Corneal Dystrophy, Ichthyosis nigrans, Microcephaly and Mild Mental

Subnormality. A Case Report

Sammartino, A.; De Crecchio, G; Federico, A.; Loffredo, A226

Clinicopathologic Case Report

Unilateral Optic Nerve Head and Choroidal Metastases from a Bronchial Carcinoma

Hayreh, S.S.; Blodi, F.C.; Silbermann, N.N.; Summers, T.B.; Potter, P.H 232

A. Author Index 242

Subject Index 243 